\title{
MEMBRANE POTENTIAL OF OLFACTORY BULB SYNAPTOSOMAL FRACTIONS: CHARACTERIZATION WITH THE LIPOPHILIC CATION TETRAPHENYLPHOSPHONIUM ${ }^{1}$
}

\author{
SARAH ROCHEL, DAVID LICHTSTEIN, ${ }^{2}$ ARTHUR J. BLUME, AND FRANK L. MARGOLIS ${ }^{3}$
}

Department of Physiological Chemistry and Pharmacology, Roche Inslilule of Molecular Biology, Nutley, New Jersey 07110

\begin{abstract}
The membrane potential of olfactory bulb synaptosomal fractions was monitored with the lipophilic cation tetraphenylphosphonium $\left(\mathrm{TPP}^{+}\right)$, which has been reported to distribute across membranes according to the Nernst equation. The properties of the synaptosomal membrane potential as monitored with $\mathrm{TPP}^{+}$were similar to those reported for neural tissues using other measurement techniques. There is an electrical potential $(\Delta \Psi)$ of -64 and $-77 \mathrm{mV}$ in the $P_{1}$ and $P_{2}$ synaptosomal fractions, respectively. This potential is due primarily to the $\mathrm{K}^{+}$diffusion gradient across the synaptosomal membrane.

The influence of ouabain on TPP ${ }^{+}$accumulation indicates that the $\left(\mathrm{Na}^{+}, \mathrm{K}^{+}\right)$-ATPase electrogenicity contributes about $-20 \mathrm{mV}$ to the resting synaptosomal membrane potential. Veratridine induced a decline in $\mathrm{TPP}^{+}$accumulation which was blocked by tetrodotoxin or by the omission of $\mathrm{Na}^{+}$from the medium.

A significant mitochondrial contribution to $\mathrm{TPP}^{+}$accumulation, which varied as a complex function of $\mathrm{TPP}^{+}$concentration in the medium in a manner indicating that $\mathrm{TPP}^{+}$interfered with the maintenance of mitochondrial potential, was observed. This mitochondrial contribution could be eliminated by performing the experiments anaerobically in the presence of oligomycin. The results are discussed with relation to the future possible use of $\mathrm{TPP}^{+}$for $\Delta \Psi$ measurements in synaptosomal preparations.
\end{abstract}

Nerve endings (synaptosomes), prepared by homogenization of brain tissue under conditions of moderate shear (for review, see Whittaker, 1969), are an important in vitro system for the study of processes associated with binding, uptake, metabolism, and release of neurotransmitters (Cotman et al., 1976; for review, see Baldessarini and Karobath, 1973; Levi and Raiteri, 1976). Such preparations have been shown to retain many of the metabolic (Bradford, 1969, 1975), osmotic (White and Keen, 1979; Keen and White, 1971), and morphological properties of the neural tissue of origin and to contain one or more mitochondria (Whittaker, 1969). In addition, synapto-

\footnotetext{
${ }^{1}$ We wish to thank Dr. James D. Hirsch for binding site measurements, Ms. Nurit Grannot-Reisfeld for determination of carnosine, glutamate decarboxylase, and tyrosine hydroxylase levels, Dr. Miloslav Boublik and Mr. Franklin Jenkins for their help in the preparation of fractions for the electron microscopic studies, and Dr. H. R. Kaback for helpful counsel. Portions of this paper are from a thesis submitted by S. R. to The Graduate Department of Biochemistry, City University of New York in partial fulfillment of the requirements for a doctoral degree.

${ }^{2}$ Present address: Department of Physiology, The Hebrew University Hadassah Medical School, Jerusalem, Israel.

${ }^{3}$ To whom correspondence should be addressed.
}

somes possess extremely active ion transport systems $(\mathrm{Li}$ and White, 1977) which maintain selective distribution of $\mathrm{Na}^{+}, \mathrm{K}^{+}$, and $\mathrm{Cl}^{-}$across the synaptosomal membrane (Campbell, 1976).

An important question that has to be addressed is: do synaptosomes maintain a $\Delta \Psi^{4}$ which regulates and is regulated by other components in a normal manner so as to provide a model system to study neuronal function? However, measurement of changes in synaptosomal membrane potential $(\Delta \Psi)$ associated with the above processes cannot be performed by direct electrophysiological techniques. Evaluation of the synaptosomal plasma membrane $\Delta \Psi$ by monitoring changes in cyanine dye fluorescence (Blaustein and Goldring, 1975; Ng and Howard, 1978; Sen and Cooper, 1978) or calculations

\footnotetext{
${ }^{4}$ The abbreviations used are: Ar, argon; CCCP, carbonyl cyanide $m$ chlorophenyl hydrazone; DHM, dihydromorphine; Dz, diazepam; GABA, $\gamma$-aminobutyric acid; GAD, glutamate decarboxylase; HEPES, 4-(2-hydroxyethyl)-1-piperazine-ethanesulfonic acid; MDPF, 2-methoxy-2,4-diphenyl-3(2H)-furanone; oligo, oligomycin; Oua (or ouab), ouabain; QNB, quinuclidinyl benzilate; SPI, spiroperidol; TH, tyrosine hydroxylase; $\mathrm{TPMP}^{+}$, methyltriphenylphosphonium; $\mathrm{TPP}^{+}$, tetraphenylphosphonium; Tris, tris(hydroxymethyl)aminomethane; 'T'X, tetrodotoxin; Ver, veratridine; $\Delta \Psi$, transmembrane potential.
} 
based on the $\mathrm{Na}^{+}, \mathrm{K}^{+}$, and $\mathrm{Cl}^{-}$distribution across the synaptosomal membrane (Campbell, 1976) or the diffusion potential of $\mathrm{Rb}^{+}$(Scott and Nicholls, 1979, 1980) each suffer from different problems (Sims et al., 1974; Simons, 1976; Kinnally and Tedeschi, 1977; Krasne, 1977; Montecucco et al., 1979; Hansson et al., 1980).

The radioactive permeant lipophilic cations, such as methyltriphenylphosphonium (TPMP') and tetraphenylphosphonium $\left(\mathrm{TPP}^{+}\right)$, have been used to measure membrane potential in mitochondria (Grinius et al., 1970), in bacteria and bacterial vesicles (H. R. Kaback, personal communication), and recently also in intrasynaptosomal mitochondria (Scott and Nicholls, 1979, 1980), neuroblastoma glioma hybrid cells (Lichtstein et al., 1979), and guinea pig synaptosomes (Ramos et al., 1979; Creveling et al., 1980).

In the present paper, we have evaluated critically the utility of $\left.{ }^{3} \mathrm{H}\right] \mathrm{TPP}^{+}$for studying the membrane potential properties of mammalian synaptosomal preparations. In particular, we have studied preparations from rat olfactory bulbs. This is a brain area rich in dendrodendritic synapses (Shepherd, 1977; Kornguth et al., 1979; Quinn and Cagan, 1980) and about which we have recently learned a great deal regarding the occurrence and distribution of neurotransmitters and neurotransmitter-related biochemistry (Nadi et al., 1980a, b; for reviews, see Margolis, 1974, 1981).

\section{Materials and Methods}

$\left.{ }^{3} \mathrm{H}\right] \mathrm{TPP}^{+}(2.5 \mathrm{Ci} / \mathrm{mmol})$ was generously supplied by Dr. H. R. Kaback (Roche Institute of Molecular Biology, Nutley, $\mathrm{NJ}$ ). TPP $^{+}$bromide was purchased from K \& K Laboratories (Plainview, NY). Veratridine was from Sigma Chemical Co. (St. Louis, MO). Tetrodotoxin, ouabain, oligomycin, and carbonyl cyanide $m$-chlorophenyl hydrazone (CCCP) were purchased from Calbiochem (La Jolla, CA). The radioactive compounds $-\left[{ }^{3} \mathrm{H}\right] \mathrm{H}_{2} \mathrm{O}(0.1$ $\mathrm{Ci} / \mathrm{gm}),\left[\right.$ methoxy $\left.{ }^{14} \mathrm{C}\right]$ inulin $(15.0 \mathrm{mCi} / \mathrm{gm}), \beta-\left[1{ }^{14} \mathrm{C}\right] \mathrm{al}-$ anine $(55 \mathrm{mCi} / \mathrm{mmol})$, (ring) $\left[3,5-{ }^{3} \mathrm{H}\right]$ tyrosine $(53.2 \mathrm{Ci} /$ mmol), $\left[1-{ }^{14} \mathrm{C}\right]$ glutamate $(23 \mathrm{mCi} / \mathrm{mmol}),\left[{ }^{3} \mathrm{H}-\right.$ methyl $] \mathrm{di}-$ azepam $(39.1 \mathrm{Ci} / \mathrm{mmol}),\left[{ }^{3} \mathrm{H}-(\mathrm{N})\right.$-methylene $]$ muscimol $(12.1 \mathrm{Ci} / \mathrm{mmol})$, and $\left[1-\right.$ phenyl $\left.-4-{ }^{3} \mathrm{H}\right]$ spiroperidol $(26.4$ $\mathrm{Ci} / \mathrm{mmol}$ ) - were all from New England Nuclear (Boston, MA). The following were obtained from Amersham Corp. (Arlington Heights, IL): $\left[1,7,8(\mathrm{~N}) \cdot{ }^{3} \mathrm{H}\right]$ dihydromorphine $(81 \mathrm{Ci} / \mathrm{mmol})$ and $\mathrm{DL}-\left[3-{ }^{3} \mathrm{H}\right]$ quinuclidinyl benzilate $(13$ and $16 \mathrm{Ci} / \mathrm{mmol}) .\left[{ }^{3} \mathrm{H}\right]$ Carnosine was synthesized in this laboratory from $\beta-\left[3-{ }^{3} \mathrm{H}(\mathrm{N})\right]$ alanine $(36 \mathrm{Ci} / \mathrm{mmol})$ obtained from New England Nuclear and unlabeled L-histidine using the method of Hirsch et al. (1978) described previously. All other chemicals used were of analytical grade.

Olfactory bulbs were obtained from inbred WKY rats raised in a germ-free colony at Hoffmann-La Roche, Inc. (Nutley, NJ). Two- to 3-month-old female rats were sacrificed by exsanguination following $\mathrm{CO}_{2}$ asphyxiation, and the olfactory bulbs were removed rapidly and placed on ice.

Synaptosomal preparation. Olfactory bulbs were homogenized (according to Hajos et al., 1974; as adapted by Keller, 1975) in $10 \mathrm{vol}$ of $0.32 \mathrm{M}$ sucrose, $1 \mathrm{mM} \mathrm{MgSO}_{4}$, and $5 \mathrm{~mm}$ HEPES/Tris ( $\mathrm{pH} 7.4$ ) by 50 strokes with a
Dounce homogenizer (Kontes) $\left(\mathrm{H}_{0}\right)$ followed by sequential filtration through 1,000-, 210-, and 70-mm mesh nylon bolting cloth $\left(\mathrm{H}_{1}\right)$, with subsequent centrifugation at $1,000 \times g$ for $1 \mathrm{~min}$ to yield a pellet $\left(\mathrm{P}_{0}\right)$ and a supernatant $\left(S_{0}\right)$. $S_{0}$ was recentrifuged at $1,000 \times g$ for $10 \mathrm{~min}$ to give pellet $P_{1}$ and supernatant $S_{1} . S_{1}$ then was centrifuged at $14,500 \times g$ for $20 \mathrm{~min}$ to give pellet $P_{2}$ and final supernatant $S_{2}$. The pellets were resuspended gently in $1 \mathrm{ml}$ of homogenization medium for each gram of starting material.

Synaptosomal characterization. Synaptosomal fractions were prepared for electron microscopy according to a modification of the method of Cotman and Flansburg (1970) by fixation with $1 \%$ osmium tetroxide in Beem capsules, dehydration with increasing concentrations of acetone, and embedding in Epon 812. Embedded pellets ( $1 \mathrm{~mm}$ thick) were sectioned in a plane perpendicular to the axis of centrifugation in order to be able to evaluate all of the components of the fraction.

To monitor the distribution of newly synthesized carnosine in the synaptosomal fractions, animals were subjected to intranasal lavage with $25 \mu \mathrm{Ci}$ of $\beta-\left[1-{ }^{14} \mathrm{C}\right]$ alanine on the evening before death. The synaptosomal $\left[{ }^{14} \mathrm{C}\right]$ carnosine content was determined as described previously by Margolis and Grillo (1977). Carnosine was determined chemically as the fluorescent 2-methoxy-2,4diphenyl-3(2H)-furanone (MDPF) derivative essentially as previously described (Wideman et al., 1978) but using an isocratic rather than stepwise elution procedure. Glutamate decarboxylase activity was monitored as the release of ${ }^{14} \mathrm{CO}_{2}$ from $\left[1{ }^{14} \mathrm{C}\right]$ glutamate according to $\mathrm{Bax}-$ ter (1972) as modified by Margolis et al. (1974). Tyrosine hydroxylase activity was evaluated by monitoring the formation of $\left[{ }^{3} \mathrm{H}\right] \mathrm{H}_{2} \mathrm{O}$, resulting from hydroxylation of 3,5-[ $\left.{ }^{3} \mathrm{H}\right]$ tyrosine as discussed by Nadi et al. $(1980 \mathrm{~b})$.

Binding sites for the ligands spiroperidol (SPI), dihydromorphine (DHM), quinuclidinyl benzilate (QNB), diazepan (DZ), muscimol, and carnosine were assayed as previously described by Nadi et al. (1980a).

DNA content was determined according to Burton (1956), and proteins were estimated by the dye binding method of Sedmak and Grossberg (1977) with bovine serum albumin as the standard. Insoluble proteins were dissolved in a small volume of formic acid and diluted for assay so that the final concentration of formic acid in the reaction mixture was $1 \%$.

$\left.l^{3} \mathrm{H}\right] T P P^{+}$accumulation. Synaptosomal fractions $\mathrm{P}_{1}$ and $\mathrm{P}_{2}$ were resuspended individually in homogenization medium and 10- $\mu$ l aliquots containing 50 to $120 \mu \mathrm{g}$ of protein were incubated at $37^{\circ} \mathrm{C}$ for $5 \mathrm{~min}$ in $200 \mu \mathrm{l}$ of either low $\mathrm{K}^{+}$medium $(121.5 \mathrm{~mm} \mathrm{NaCl}+5 \mathrm{mM} \mathrm{KCl})$, high $\mathrm{K}^{+}$medium $(121.5 \mathrm{mM} \mathrm{KCl}+5 \mathrm{mM} \mathrm{NaCl})$, or choline medium (121.5 $\mathrm{mM}$ choline chloride $+5 \mathrm{mM}$ $\mathrm{KCl})$. In addition, all of the incubation media contained $0.25 \mu \mathrm{Ci}$ of $5 \mu \mathrm{M}\left[{ }^{3} \mathrm{H}\right] \mathrm{TPP}^{+}, 0.8 \mathrm{mM} \mathrm{MgSO}_{4}, 1.8 \mathrm{mM} \mathrm{CaCl}_{2}$, $1 \mathrm{~mm}$ sodium phosphate, $5.5 \mathrm{~mm}$ glucose, and $45 \mathrm{~mm}$ HEPES buffered with Tris base to $\mathrm{pH}$ 7.4. All incubations were in air unless otherwise indicated. Alterations in incubation time, additives, and composition of the medium will be specified as appropriate. Incubation was stopped by the addition of $2.5 \mathrm{ml}$ of cold $0.8 \mathrm{M} \mathrm{NaCl}$ and immediate rapid vacuum filtration through Millipore fil- 
ters (EHWP cellotate) followed by an additional wash with $2.5 \mathrm{ml}$ of $0.8 \mathrm{M} \mathrm{NaCl}$. The total filtration time for each sample was less than $20 \mathrm{sec}$. The filters then were dried at $50^{\circ} \mathrm{C}$ for $30 \mathrm{~min}$ and the radioactivity was determined in a liquid scintillation spectrometer in the presence of $10 \mathrm{ml}$ of Hydrofluor (National Diagnostics, Parsippany, NJ).

Synaptosomal volume. The internal synaptosomal volume was evaluated using $\left[\operatorname{methoxy-}{ }^{14} \mathrm{C}\right]$ inulin as an indicator of the external volume and $\left[{ }^{3} \mathrm{H}\right] \mathrm{H}_{2} \mathrm{O}$ as an indicator of the total volume, basically according to the procedure described by Schuldiner and Kaback (1975). The synaptosomal volume is defined as the calculated difference between the total volume and the external volume.

An aliquot of synaptosomal suspension $(30 \mu \mathrm{l}, 500 \mu \mathrm{g}$ of protein) was added to $470 \mu \mathrm{l}$ of the same buffer composition as in the various $\mathrm{TPP}^{+}$accumulation studies but which contained in addition $0.5 \mu \mathrm{Ci}$ of $\left[{ }^{3} \mathrm{H}\right] \mathrm{H}_{2} \mathrm{O}$ and $0.05 \mu \mathrm{Ci}$ of $\left[{ }^{14} \mathrm{C}\right.$ ]inulin. After rapid mixing, the samples were centrifuged immediately for $30 \mathrm{sec}$ at about 15,000 $\times g$ in an Eppendorf Microfuge. An aliquot of supernatant was taken from each tube for the determination of the contents of ${ }^{3} \mathrm{H}$ and ${ }^{14} \mathrm{C}$ to evaluate the total input. After removal of the balance of the supernatant by aspiration, the pellet was dissolved in $0.5 \mathrm{ml}$ of $1 \%$ sodium dodecyl sulfate at room temperature overnight, transferred quantitatively to scintillation vials with $1 \mathrm{ml}$ of $\mathrm{H}_{2} \mathrm{O}$, and counted in $10 \mathrm{ml}$ of Hydrofluor with the appropriate standards. Internal synaptosomal volumes of 6.6 $\pm 0.53 \mathrm{SD} \mu \mathrm{l} / \mathrm{mg}$ of protein for $\mathrm{P}_{1}$ and $5.5 \pm 0.51 \mathrm{SD} \mu \mathrm{l} /$ $\mathrm{mg}$ of protein for $\mathrm{P}_{2}$ were obtained. No significant variation in volumes was observed under isotonic conditions with changes in $\mathrm{K}^{+}$concentrations and drug additions.

Calculation of $\left[{ }^{3} H\right] T P P^{+}$gradient and $\triangle \Psi$. The transmembrane potential $(\Delta \Psi)$ of the synaptosomes was calculated based on the distribution of $\left[{ }^{3} \mathrm{H}\right] \mathrm{TPP}^{+}$according to adaptation of the Nernst equation:

$$
\Delta \Psi=\frac{-R T}{Z F^{+}} \ln \left[\mathrm{TPP}^{+}\right]_{\mathrm{in}} /\left[\mathrm{TPP}^{+}\right]_{\mathrm{mut}}
$$

which at $37^{\circ} \mathrm{C}$ simplifies to:

$$
\Delta \Psi=61.5 \log \left[\mathrm{TPP}^{+}\right]_{\text {in }} /\left[\mathrm{TPP}^{+}\right]_{\text {out }}
$$

where:

$$
\left[\mathrm{TPP}^{+}\right]_{\text {in }}=\left[\mathrm{TPP}^{+}\right]_{\text {in }}^{\text {low } \mathrm{K}^{+}}-\left[\mathrm{TPP}^{+}\right]_{\text {in }}^{\text {high } \mathrm{K}^{+}}
$$

This correction (equation 3 ) is based on the assumption that the accumulation of $\left[{ }^{3} \mathrm{H}\right] \mathrm{TPP}^{+}$in the presence of depolarizing concentrations of extracellular potassium $(122 \mathrm{mM})$ is not due to the synaptosomal membrane potential as discussed by Lichtstein et al. (1979). The ratio:

$$
\left[\mathrm{TPP}^{+}\right]_{\text {in }} /\left[\mathrm{TPP}^{+}\right]_{\text {out }}=\mathrm{TPP}^{+} \text {gradient }
$$

Equations 4 and 2 were the basic equations used in this study to calculate the $\left[{ }^{3} \mathrm{H}\right] \mathrm{TPP}^{+}$gradient and membrane potential, respectively. Certain modifications of these equations have been derived in the text in order to adapt them to the specific problems of $\Delta \Psi$ quantitation in olfactory bulb synaptosomes.

\section{Results}

Synaptosomal fraction characterization. The olfactory bulb synaptosomal fractions have been characterized both morphologically and biochemically.

Electron microscopic observations (Fig. 1) indicated that fraction $\mathrm{P}_{0}$ consists primarily of nuclei and unbroken cells. Fraction $\mathrm{P}_{1}$ contains multisynaptosomal particles, occasional nuclei, and some unidentified membranes. Fraction $\mathrm{P}_{2}$ contains primarily individual synaptosomes as identified by their content of internal mitochondria, synaptic vesicles, and postsynaptic densities, as well as some unidentified particles and occasional free mitochondria.

The distribution of DNA in the various homogenate subfractions (Table I) supports the conclusion obtained from the electron microscopic study that most of the nuclei in the original homogenate $\left(\mathrm{H}_{0}\right)$ are removed into the $\mathrm{P}_{0}$ fraction since only a small amount of the homogenate DNA is observed in the $P_{1}$ fraction, and no DNA could be detected in the $\mathrm{P}_{2}$ or $\mathrm{S}_{2}$ fractions. The distribution of the activity of the neurotransmitter-synthesizing enzymes, glutamate decarboxylase (GAD) and tyrosine hydroxylase (TH) (Table I), shows that about $75 \%$ of GAI and $44 \%$ of ' $\mathrm{IH}$ activities are associated with the particulate fractions. Their distribution among $\mathrm{P}_{0}, \mathrm{P}_{1}$, and $\mathrm{P}_{2}$ is uniform. Carnosine ( $\beta$-alanyl-L-histidine) is specifically associated with olfactory neuron terminals in the bulb (Margolis et al., 1974; Margolis, 1974; Ferriero and Margolis, 1975; Hirsch and Margolis, 1979; Nadi et al., 1980a). The distribution pattern of this dipeptide among the particulate fractions is very similar whether measured chemically or as newly synthesized $\left[{ }^{14} \mathrm{C}\right]$ carnosine ('Table I). Much more of the dipeptide carnosine is present in the final supernatant than is seen for either of the two enzyme activities studied.

The distribution of ligand binding sites (Table II) among the olfactory bulb homogenate subfractions shows that the fractions can be differentiated according to their binding site compositions. Spiroperidol and carnosine binding are enriched in $\mathrm{P}_{1}$, while $\mathrm{QNB}$ binding is highest in $\mathrm{P}_{2}$. Muscimol, DHM, and DZ binding distribute similarly among the $P_{0}, P_{1}$, and $P_{2}$ fractions. Thus, fractions $P_{1}$ and $P_{2}$ share many basic synaptosomal characteristics, such as neurotransmitter binding sites, carnosine content, GAD and TH activity, and some morphological properties, while they differ from one another in the morphological appearance of multi- versus monosynaptosomal particles and in the distribution of certain neurotransmitter binding sites. These may serve as an indicator of the area of origin of $P_{1}$ and $P_{2}$ particles in the olfactory bulb which, together with the resting membrane potential properties (to be described next), will facilitate further in vitro study of olfactory bulb function.

$T P P^{\prime}$ accumulation in synaptosomes. When the olfactory bulb synaptosomal fractions $P_{1}$ and $P_{2}$ were incubated in low $\mathrm{K}^{+}$medium with $5 \mu \mathrm{M} \mathrm{TPP}^{+}$, accumulation of this cation was rapid for the first $2 \mathrm{~min}(80 \%$ of maximum) and achieved steady state levels by $5 \mathrm{~min}$ (see below) which were maintained for $1 \mathrm{hr}$. At this time, the $\mathrm{TPP}^{+}$concentration gradients $\left(\left[\mathrm{TPP}^{+}\right]_{\mathrm{in}} /\left[\mathrm{TPP}^{+}\right]_{\text {out }}\right)$ were 25 for $P_{1}$ and 39 for $P_{2}$. Based on the report of 

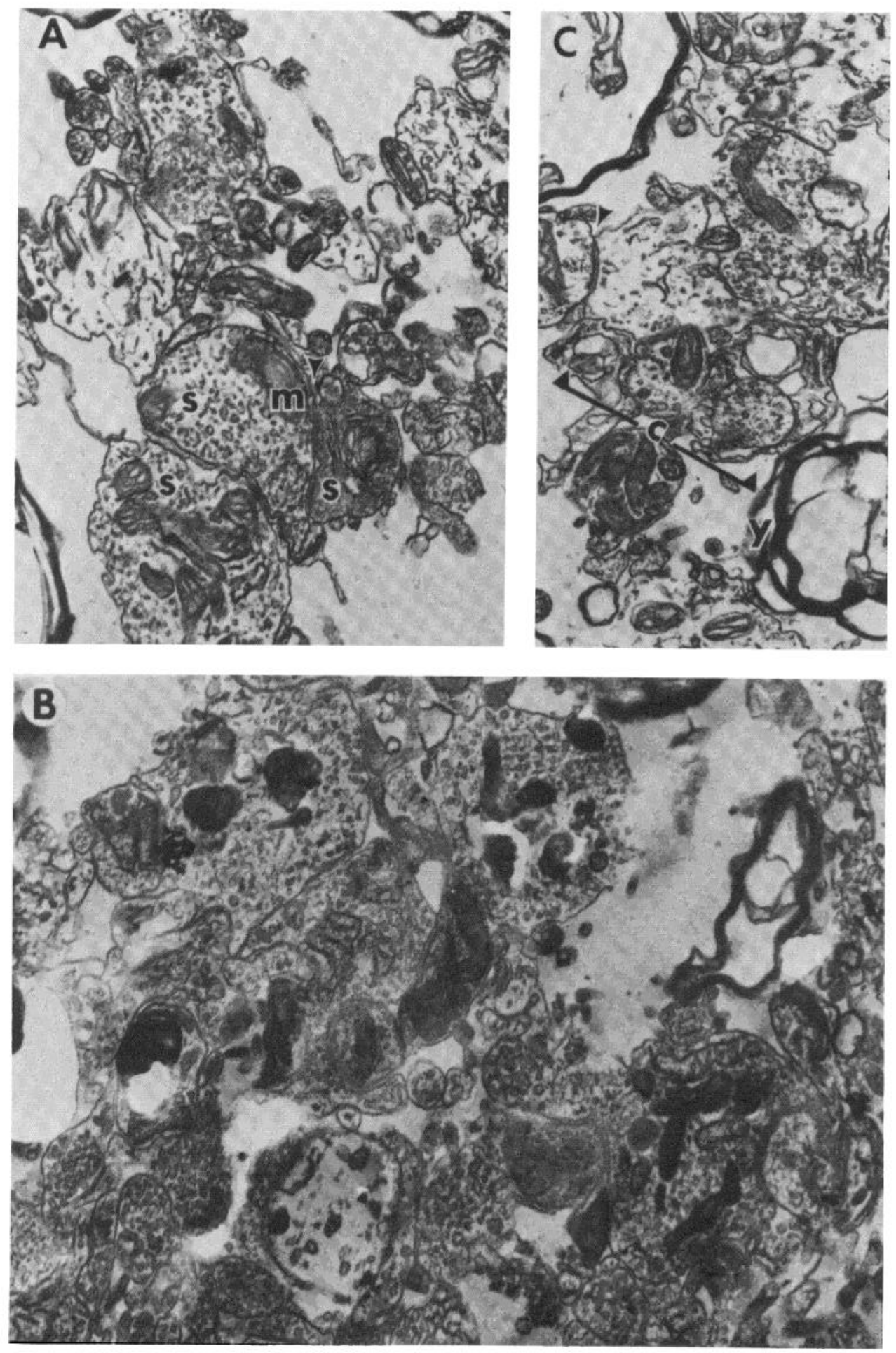

Figure 1. Electron micrographs of the synaptosomal fractions prepared from rat olfactory bulbs by gentle homogenization in $0.32 \mathrm{M}$ buffered sucrose. After removal of most of the nuclei and unbroken cells into the $P_{0}$ pellet by centrifugation at $1,000 \times g$ for $1 \mathrm{~min}$, the $P_{1}$ fraction was obtained by subsequent centrifugation of $S_{0}$ for $10 \mathrm{~min}$ at $1,000 \times g$. The $\mathrm{P}_{1}$ fraction $(A, B$, and $C$ ) contains a few nuclei (not shown) and primarily synaptosomes (s) clustered together in synaptic complexes $(c)$. Synaptic vesicles are observed as are synaptic contacts (arrowheads) with classical postsynaptic thickening of the membrane. Intrasynaptosomal mitochondria $(m)$ and a few fragments of myelinated axons $(y)$ are observed also. 

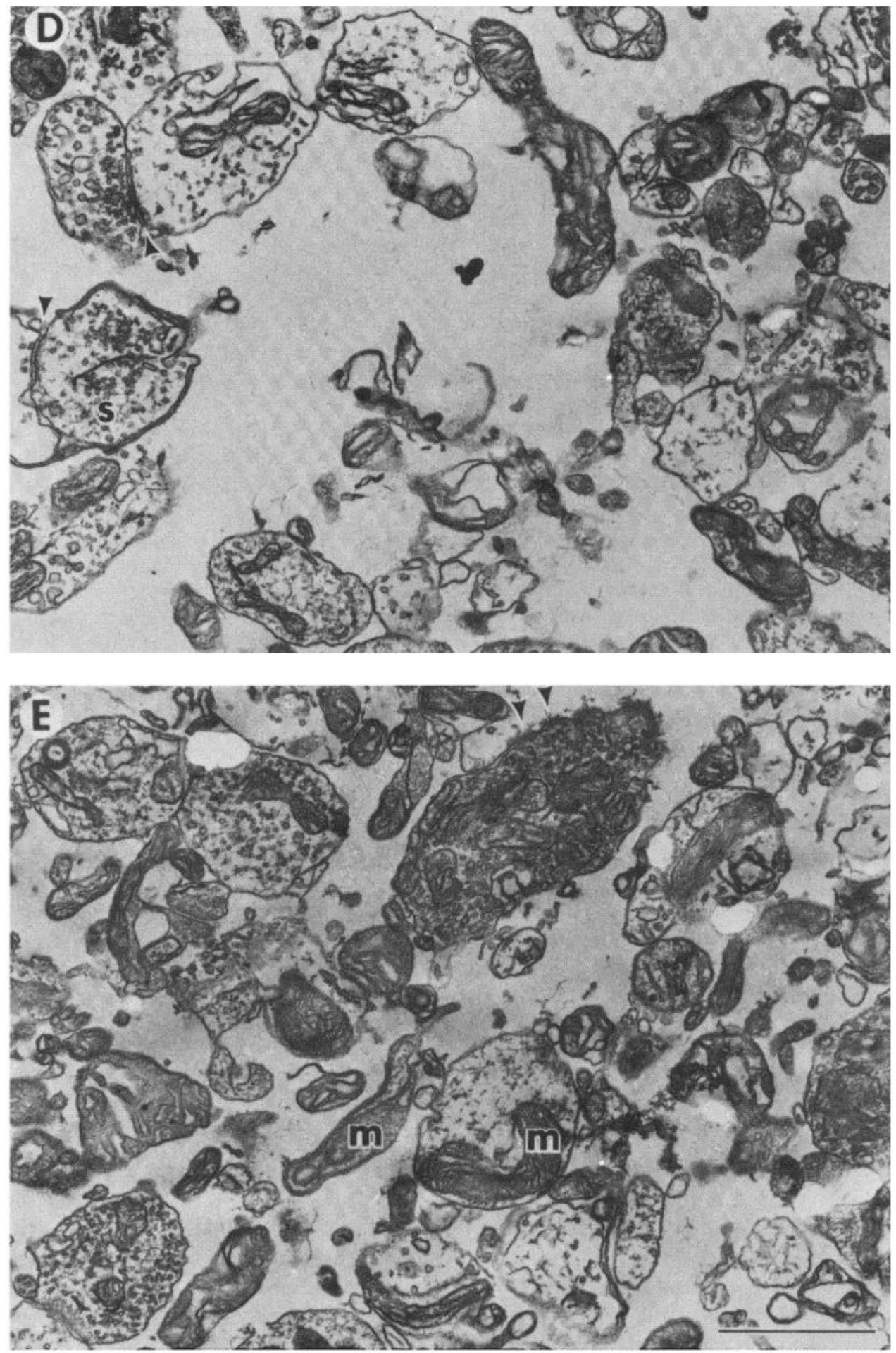

Figure 1. Continued. Fraction $\mathrm{P}_{2}(D$ and $E$ ) represents the classical crude synaptosomal pellet obtained by centrifugation of $S_{1}$ (the supernatant of $P_{1}$ ) for $20 \mathrm{~min}$ at $14,500 \times \mathrm{g}$. The legend is the same as for $\mathrm{P}_{1}$. However, $\mathrm{P}_{2}$ contains conventional synaptosomes rather than multisynaptic particles; a few free mitochondria $(m)$ are visible. No nuclei or myelinated fragments are observed. Marker bar $=1.0 \mu \mathrm{m}$.

Ramos et al. (1979) and on our studies (S. Rochel, D. Lichtstein, A. J. Blume, and F. L. Margolis, unpublished data) showing that at $5 \mu \mathrm{M} \mathrm{TPP}{ }^{+}$accumulation is a linear function of synaptosomai protein concentration in the range from 50 to $150 \mu \mathrm{g}$ of protein per assay, a concentra- tion of $5 \mu \mathrm{M} \mathrm{TPP}^{+}$was chosen for these experiments. When the protonophore CCCP was added at $5 \mathrm{~min}$, about $90 \%$ of the TPP $^{+}$associated with synaptosomes was lost in less than $1 \mathrm{~min}$. Similar results were obtained when the detergent Triton X-100 was added to the incubation 
TABLE I

Biochemical characterization of rat olfactory bulb homogenate fractions

All values are the averages of three separate preparations.

\begin{tabular}{|c|c|c|c|c|c|c|c|c|c|}
\hline & \multicolumn{3}{|c|}{ Carnosine } & \multicolumn{2}{|c|}{ Glutamic Acid Decarboxylase } & \multicolumn{2}{|c|}{ Tyrosine Hydroxylase } & \multicolumn{2}{|c|}{ DNA } \\
\hline & \multicolumn{2}{|c|}{ Chemical Analysis } & \multirow{2}{*}{$\begin{array}{c}\begin{array}{c}\text { Radioactive } \\
\text { Analysis }\end{array} \\
\begin{array}{c}\text { Percent Re- } \\
\text { covery }^{b}\end{array}\end{array}$} & \multirow{2}{*}{$\begin{array}{l}\text { Percent Re- } \\
\text { covery }^{c}\end{array}$} & \multirow{2}{*}{$\begin{array}{c}\mathrm{nmol} / \mathrm{min} / \mathrm{mg} \text { of } \\
\text { Protein }\end{array}$} & \multirow{2}{*}{$\begin{array}{l}\text { Percent Re- } \\
\text { covery }^{d}\end{array}$} & \multirow{2}{*}{$\begin{array}{c}\mathrm{pmol} / \mathrm{min} / \mathrm{mg} \text { of } \\
\text { Protein }\end{array}$} & \multirow{2}{*}{$\begin{array}{l}\text { Percent Re- } \\
\text { covery }\end{array}$} & \multirow{2}{*}{$\begin{array}{c}\mu \mathrm{g} \text { of DNA } / \mathrm{mg} \text { of } \\
\text { Protein }\end{array}$} \\
\hline & $\begin{array}{c}\text { Percent } \\
\text { Recovery }^{a}\end{array}$ & $\begin{array}{c}\mathrm{nmol} / \mathrm{mg} \text { of } \\
\text { Protein }\end{array}$ & & & & & & & \\
\hline $\mathrm{H}_{0}$ & & 23.5 & & & 12.4 & & 20.0 & & 0.035 \\
\hline $\mathrm{H}_{1}$ & & 23.5 & & & 11.9 & & 19.3 & & 0.033 \\
\hline $\mathrm{P}_{0}$ & 6.9 & 12.8 & 7.4 & 20.9 & 12.7 & 14.4 & 20.1 & 75.9 & 0.17 \\
\hline$P_{1}$ & 9.5 & 18.4 & 9.3 & 23.2 & 13.1 & 14.3 & 18.5 & 21.1 & 0.034 \\
\hline $\mathrm{P}_{2}$ & 10.5 & 11.4 & 9.9 & 28.2 & 14.2 & 14.9 & 17.2 & $<4.4$ & $<0.006$ \\
\hline $\mathrm{S}_{2}$ & 73.0 & 51.9 & 73.4 & 28.0 & 8.2 & 56.4 & 38.0 & $<3.0$ & $<0.006$ \\
\hline
\end{tabular}

${ }^{a}$ Total carnosine in the tissue was $1.5 \mathrm{nmol} / \mathrm{mg}$ of tissue.

${ }^{b}$ Represents the newly (16-hr) synthesized carnosine at about $30,000 \mathrm{cpm} / \mathrm{mg}$ of tissue.

' Initial activity for $\mathrm{H}_{0}$ was $0.57 \mathrm{nmol} / \mathrm{min} / \mathrm{mg}$ of tissue.

${ }^{d}$ Initial activity for $\mathrm{H}_{0}$ was $1.3 \mathrm{pmol} / \mathrm{min} / \mathrm{mg}$ of tissue.

${ }^{\circ}$ Represents the percentage of total DNA in tissue $(3.15 \mu \mathrm{g}$ of DNA/mg of tissue) that was recovered in each fraction.

TABLE II

Distribution of ligand binding sites in olfactory bulb fractions

The unlabeled competitor is indicated in parentheses below the labeled ligand. Binding was estimated as previously described (Nadi et al., $1980 \mathrm{a})$. All values are the averages of two separate preparations.

\begin{tabular}{|c|c|c|c|c|c|c|}
\hline Fraction & $\begin{array}{c}{\left[{ }^{3} \mathrm{H}\right] \mathrm{SPI}} \\
\text { (Dopamine) }\end{array}$ & $\begin{array}{c}{\left[{ }^{3} \mathrm{H}\right] \mathrm{DHM}} \\
\text { (Levallorphan) }\end{array}$ & $\begin{array}{l}{\left[{ }^{3} \mathrm{H}\right] \mathrm{QNB}} \\
\text { (Atropine) }\end{array}$ & $\begin{array}{c}{\left[{ }^{3} \mathrm{H}\right] \mathrm{DZ}} \\
\text { (Diazepam) }\end{array}$ & $\begin{array}{c}{\left[{ }^{3} \text { H]Muscimol }\right.} \\
\text { (GABA) }\end{array}$ & $\begin{array}{l}{\left[{ }^{3} \text { H]Carnosine }\right.} \\
\text { (Camosine) }\end{array}$ \\
\hline $\mathrm{H}_{1}$ & 26 & 59 & 1153 & 757 & 901 & 216 \\
\hline$P_{0}$ & 106 & 24 & 581 & 469 & 459 & 97 \\
\hline$P_{1}$ & 171 & 40 & 1035 & 733 & 726 & 257 \\
\hline $\mathbf{P}_{2}$ & 68 & 39 & 1377 & 668 & 706 & 147 \\
\hline
\end{tabular}

TABLE III

pH effect on $T P P^{+}$accumulation

Synaptosomes were incubated at $37^{\circ} \mathrm{C}$ for $5 \mathrm{~min}$ in low $\mathrm{K}^{+}(4.5 \mathrm{mM})$ medium at various external $\mathrm{pH}$ and $\mathrm{TPP}^{+}$accumulations were compared to $\mathrm{pH}$ 7.4. Values are the averages of three separate preparations.

\begin{tabular}{crc}
\hline & \multicolumn{2}{c}{ Percent of $\mathrm{TPP}^{+}$Accumulation at $\mathrm{pH}$ 7.4 } \\
\cline { 2 - 3 } & $\mathrm{P}_{1}$ & $\mathrm{P}_{2}$ \\
\hline 6.7 & 80 & 74 \\
7.0 & 100 & 92 \\
7.2 & 95 & 94 \\
7.4 & 100 & 100 \\
7.6 & 101 & 101 \\
7.8 & 88 & 87 \\
8.0 & 88 & 90 \\
\hline
\end{tabular}

medium at a final concentration of $0.5 \%$ or when the synaptosomes were lysed with distilled water after the steady state level of $\mathrm{TPP}^{+}$accumulation was achieved. Furthermore, $\mathrm{TPP}^{+}$that is accumulated exhibits no alteration in the $\mathrm{BuOH}: \mathrm{H}_{2} \mathrm{O}$ distribution coefficient or mobility on thin layer chromatography, indicating that $\mathrm{TPP}^{+}$is unaltered during these incubations. These results also indicate that the plateau levels of accumulation represent a reversible steady state accumulation of $\mathrm{TPP}^{+}$ (rather than conversion of $\mathrm{TPP}^{+}$into a stable internal component of the synaptosomes).
Influence of $\mathrm{pH}$ on the accumulation of $\mathrm{TPP}^{+}$. The internal $\mathrm{pH}$ of nerve cells was reported to be 6.7 to 7.1 (Arieff et al., 1976; Sundt and Anderson, 1980), while the external $\mathrm{pH}$ value of body fluids is about 7.4. It is possible that a change in one of these values could cause a change in the polarity of the plasma membrane and subsequently in the accumulation of the cation $\mathrm{TPP}^{+}$. $\mathrm{TPP}^{+}$uptake was independent of external $\mathrm{pH}$ in the range 7 to 7.6 (Table III). Since TPP ${ }^{+}$uptake declined outside of this range, it is clear that the optimum external $\mathrm{pH}$ for maintaining $\Delta \Psi$ in the synaptosomes is near that of normal extracellular $\mathrm{pH}$.

Influence of potassium concentration on membrane potential and mitochondrial contribution. Intrasynaptosomal mitochondria might be expected to accumulate $\mathrm{TPP}^{+}$in a cascade fashion as a function of the cytoplasmic $\mathrm{TPP}^{+}$concentration, thus contributing to the total observed synaptosomal content of $\mathrm{TPP}^{+}$. An indication of the mitochondrial contribution is the observation that $\Delta \Psi$ values decline in the presence of oligomycin/argon. Thus, the mitochondrial proton electrochemical gradient complicates the determination of $\Delta \Psi$ with $\mathrm{TPP}^{+}$. The effect of varying external potassium concentrations on the plasma membrane potential of rat olfactory bulb synaptosomal fractions therefore was evaluated in the absence and presence of oligomycin/argon (Fig. 2). 


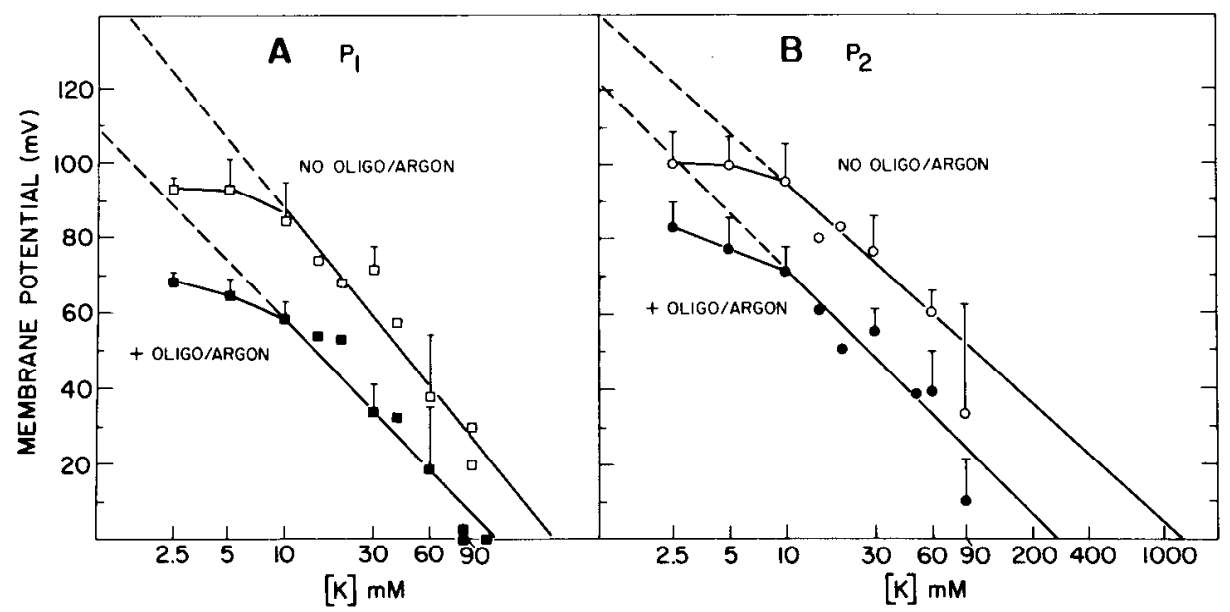

Figure 2. Effect of potassium concentration on membrane potential. $\mathrm{TPP}^{+}$accumulation was measured in the presence of 0 to $150 \mathrm{mM} \mathrm{K}{ }^{+}$concentrations. The reaction was initiated by adding $\left[{ }^{3} \mathrm{H}\right] \mathrm{TPP}^{+}(5 \mu \mathrm{M})$ to synaptosomes that were pre-equilibrated with $\mathrm{K}^{+}$buffer in air or in oligomycin/argon for $5 \mathrm{~min}$ at $37^{\circ} \mathrm{C}$. The reaction was stopped after $5 \mathrm{~min}$ by rapid vacuum filtration. Data are presented as the averages of three determinations $\pm \mathrm{SD}$ or of single determinations. The limiting slope was calculated using membrane potential values obtained for $10 \mathrm{mM} \mathrm{K}{ }^{+}$or higher. Panel $A$, fraction $\mathrm{P}_{1} ;$ panel $B$, fraction $\mathrm{P}_{2}$. $\square\left(\mathrm{P}_{1}\right)$ and $\bigcirc\left(\mathrm{P}_{2}\right)$, in air (no oligo/Ar); $\left(\mathrm{P}_{1}\right)$ and $\left(\mathrm{P}_{2}\right)$, with oligo/Ar. Calculation of the logarithmic regression of the Nernst equation:

$$
\Delta \Psi=a-b \log \left[\mathrm{K}^{+}\right]_{\text {out }}
$$

where

$$
\Delta \Psi=b \log \left[\mathrm{K}^{+}\right]_{\text {in }}-b \log \left[\mathrm{K}^{+}\right]_{\text {ont }}
$$

resulted in the following regression parameters:

$\begin{array}{ccccc} & & b & R^{2} \\ \mathrm{P}_{1} & \text {-oligo/Ar } & 149 & 60 & 0.78 \\ & \text { +oligo/Ar } & 109 & 50 & 0.74 \\ \mathrm{P}_{2} & \text {-oligo/Ar } & 141 & 45 & 0.83 \\ & \text { +oligo/Ar } & 123 & 50 & 0.80\end{array}$

$R^{2}$ is the correlation coefficient.

The membrane potentials observed in the presence of $5 \mathrm{mM}$ external $\mathrm{K}^{+}$under oligomycin/argon are $-64 \mathrm{mV}$ for $P_{1}$ and $-77 \mathrm{mV}$ for $P_{2}$ and are in good agreement with values reported in nervous tissue by various methods, while the $\Delta \Psi$ values observed in air are higher, $-86 \mathrm{mV}$ for $P_{1}$ and $-98 \mathrm{mV}$ for $P_{2}$, respectively. The decline in $\Delta \Psi$ in response to increasing external $K^{+}$either in the presence or in the absence of oligomycin/argon (Fig. 2) demonstrates the dependence of the membrane potential on the external potassium concentration, with limiting slopes somewhat smaller than the expected value of 61.5 , assuming:

$$
\Delta \Psi=-61.5 \log \left[\mathrm{K}^{+}\right]_{\text {in }} /\left[\mathrm{K}^{+}\right]_{\text {out }}
$$

The experimental data deviate from the Nernst equation above at concentrations of external $\mathrm{K}^{+}$below $10 \mathrm{~mm}$, indicating the presence of an additional small contribution to the synaptosomal $\Delta \Psi$, possibly from $\mathrm{Na}^{+}$conductance.

In order to evaluate more carefully the contribution of the mitochondrial potential to the accumulation of $\left[{ }^{3} \mathrm{H}\right] \mathrm{TPP}^{+}$into the synaptosomal fractions, the calculated $\Delta \Psi$ values obtained in the absence of oligomycin/argon were compared with the $\Delta \Psi$ values obtained in the presence of oligomycin/argon by linear regression analysis (Fig. 3) according to the equation:

$$
\Delta \Psi_{(- \text {oligornycin/argon })}=a+b \Delta \Psi_{(+o l i g o m y c i n / a r g o n)}
$$

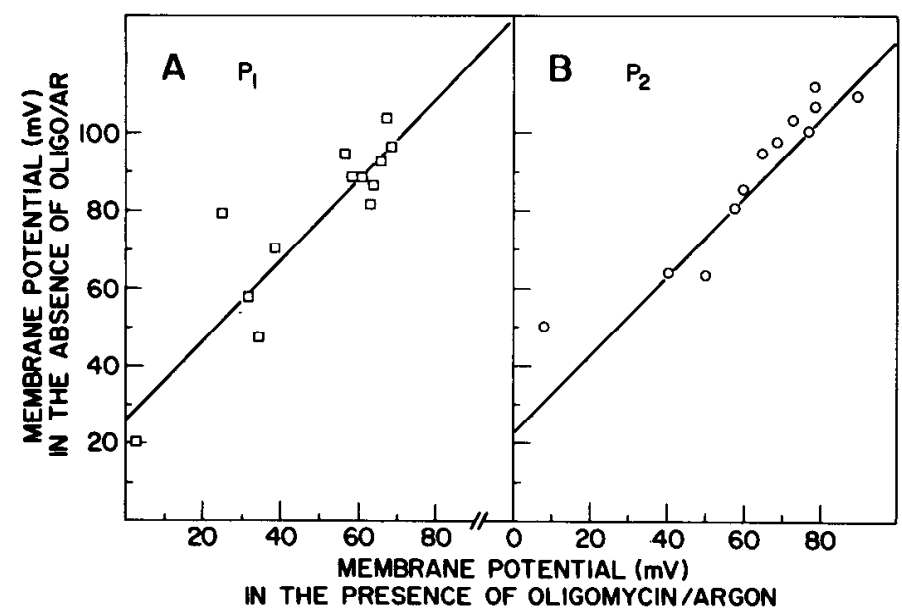

Figure 3. Linear correlation between membrane potentials obtained in the absence and in the presence of oligomycin/ argon. The experiment was performed as described in Figure 2. Membrane potentials obtained in air at each potassium concentration were plotted versus membrane potentials obtained under oligomycin/argon for the same $\mathrm{K}^{+}$concentration. Panel A, fraction $\mathrm{P}_{1}$; panel $B$, fraction $\mathrm{P}_{2}$. The correlation line parameters obtained for the linear equation of $\Delta \Psi_{\text {(-oligo/Ar) }}=a+$ $b \Delta \Psi_{(+o l i g o / A r)}$ are: for $\mathrm{P}_{1}, a=25.61$ and $b=1.03$ and the correlation coefficient $R^{2}=0.98$; and for $\mathrm{P}_{2}, a=22.6$ and $b=$ 1.01 and the correlation coefficient $R^{2}=0.91$. 
A linear correlation was obtained between the two sets of $\Delta \Psi$ values $\left(R^{2}=0.91\right.$ for $\mathrm{P}_{1}$ and 0.98 for $\left.\mathrm{P}_{2}\right)$, with a slope of approximately 1 , having the same increment in $\Delta \Psi_{\text {(-oligomycin/argon) }}$ as in the respective $\Delta \Psi_{(+ \text {oligomycin/argon) }}$. This indicates that measurement of $\left[{ }^{3} \mathrm{H}\right] \mathrm{TPP}^{+}$accumulation in the absence of oligomycin/argon, although not quantitatively measuring the synaptosomal potential due to the presence of a mitochondrial contribution (which in this case represents about $-25 \mathrm{mV}$ ), nevertheless can reflect changes in synaptosomal plasma membrane potential as long as mitochondrial potential changes are not involved. Consistent with this conclusion is the observation of a constant value for the mitochondrial contribution to total apparent synaptosomal $\Delta \Psi$ (factor $a$ ), expressed as the differences between the $\Delta \Psi$ pairs over a wide range of plasma membrane potentials and external potassium concentrations.

Time course of the effect of $\left(\mathrm{Na}^{+}, \mathrm{K}^{+}\right)$-ATPase blocker ouabain on $T P P^{+}$accumulation. The cardiac glycoside drug ouabain is a specific inhibitor of $\left(\mathrm{Na}^{+}, \mathrm{K}^{+}\right)$-ATPase (Baker, 1965; Schatzmann, 1965; Smith and Haber, 1973; Dahl and Hokin, 1974; Glynn and Karlish, 1975; Wallick et al., 1979) and was reported to have no effect on mitochondrial ATPase or mitochondrial $\Delta \Psi$ (Scott and Nicholls, 1980). Thus, its effect on $\mathrm{TPP}^{+}$accumulation was studied in order to evaluate $\left(\mathrm{Na}^{+}, \mathrm{K}^{+}\right)$-ATPase contribution to the resting synaptosomal $\Delta \Psi$.

Two aspects of ouabain on $\left[{ }^{3} \mathrm{H}\right] \mathrm{TPP}^{+}$accumulation in $P_{1}$ and $P_{2}$ fractions were observed (Fig. 4). The first was a rapid effect in which ouabain added after $\mathrm{TPP}^{+}$accumulation had achieved a steady state and caused a very rapid release of $50 \%$ of the $\mathrm{TPP}^{+}$. The second was a slowly developing effect, which became obvious after 20 min and almost completely eliminated $\mathrm{TPP}^{+}$accumulation by $1 \mathrm{hr}$ after ouabain addition. When ouabain and $\mathrm{TPP}^{+}$are added to the synaptosomal fractions simultaneously, the extent of initial $\mathrm{TPP}^{+}$accumulation is reduced but not totally blocked.

The effect of increasing concentrations of veratridine on $T P P^{+}$accumulation. The neurotoxic alkaloid verat-

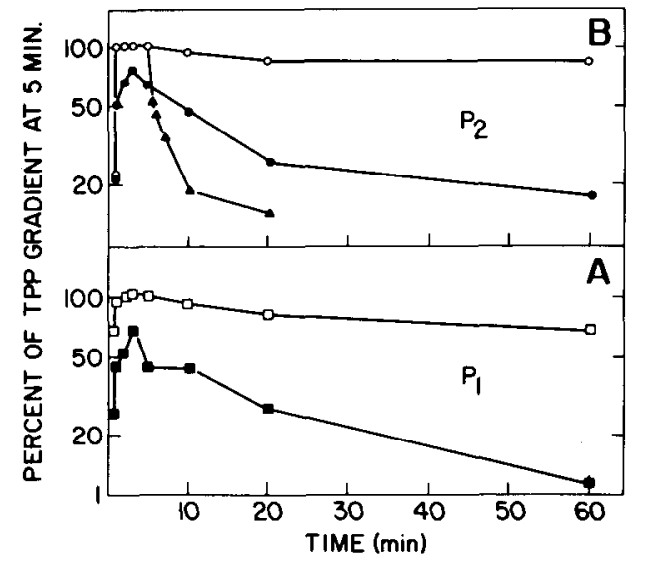

Figure 4. Time course of the ouabain effect on $\mathrm{TPP}^{+}$accumulation. Ouabain ( $10 \mathrm{~mm}$ ) was added to the synaptosomes at time $0\left(\square, P_{1} ; \ominus, P_{2}\right)$ or at 5 min $\left(\Delta, P_{2}\right)$ after the beginning of incubation with $\mathrm{TPP}^{+}$. Incubation was stopped at different time points between $30 \mathrm{sec}$ and $60 \mathrm{~min}$. Control: $\square, \mathrm{P}_{1} ; \mathrm{O}, \mathrm{P}_{2}$. Panel $A$, fraction $\mathrm{P}_{1}$; panel $B$, fraction $\mathrm{P}_{2}$. ridine causes depolarization of nerve cells or synaptosomes (Blaustein and Goldring, 1975) by keeping the action potential sodium channel constantly open, permitting electrogenic $\mathrm{Na}^{+}$influx (Ulbricht, 1969; Catterall and Nirenberg, 1973; Li and White, 1977). Veratridine caused a dose-dependent reduction of $\mathrm{TPP}^{+}$accumulation into both $\mathrm{P}_{1}$ and $\mathrm{P}_{2}$ fractions suspended in low $\mathrm{K}^{+}$ medium (Fig. 5). This resulted in a progressive fall in the $\left[{ }^{3} \mathrm{H}\right] \mathrm{TPP}^{+}$concentration gradient $\left(\left[\mathrm{TPP}^{+}\right]_{\text {in }} /\left[\mathrm{TPP}^{+}\right]_{\text {out }}\right)$ to about $50 \%$ of control at a concentration of $50 \mu \mathrm{M}$ veratridine and $25 \%$ of control at $100 \mu \mathrm{M}$. This decrease in $\mathrm{TPP}^{+}$accumulation in the presence of veratridine is consistent with veratridine acting as a depolarizing agent in our system. Based on these data, veratridine concentrations of 50 or $100 \mu \mathrm{M}$ have been chosen for use in subsequent experiments where competition or activity with other drugs was monitored.

Influence of $\Delta \Psi$-modifying drugs on $\mathrm{TPP}^{+}$accumulation and $\Delta \Psi$. In order to characterize further the mechanisms involved in the determination of synaptosomal $\Delta \Psi$, we studied the effects of $\Delta \Psi$-modifying drugs on $\mathrm{TPP}^{+}$accumulation in high and low potassium media in the presence or absence of oligomycin/argon. The specificity of this approach is derived from our previous experiments (Fig. 2). Incubation of synaptosomes in the presence of oligomycin/argon reduces the $\mathrm{TPP}^{+}$accumulation in both high and low $\mathrm{K}^{+}$media (Fig. 6). This indeed indicates that there is $\mathrm{TPP}^{+}$accumulation in mitochondria which is dependent upon the state of the mitochondria. These mitochondria continue to accumulate $\mathrm{TPP}^{+}$even in the presence of high $\mathrm{K}^{+}$in the medium. As indicated before, the cascade accumulation of TPP ${ }^{+}$ into mitochondria leads to a higher apparent $\Delta \Psi$ in air than in oligomycin/argon.

Veratridine is without effect on $\mathrm{TPP}^{+}$accumulation in the presence of high $\mathrm{K}^{+}$and oligomycin/argon (i.e., under conditions where neither synaptosomal nor mitochondrial $\Delta \Psi$ exists). However, in the presence of low $\mathrm{K}^{+}$ medium, veratridine causes the same proportional loss in

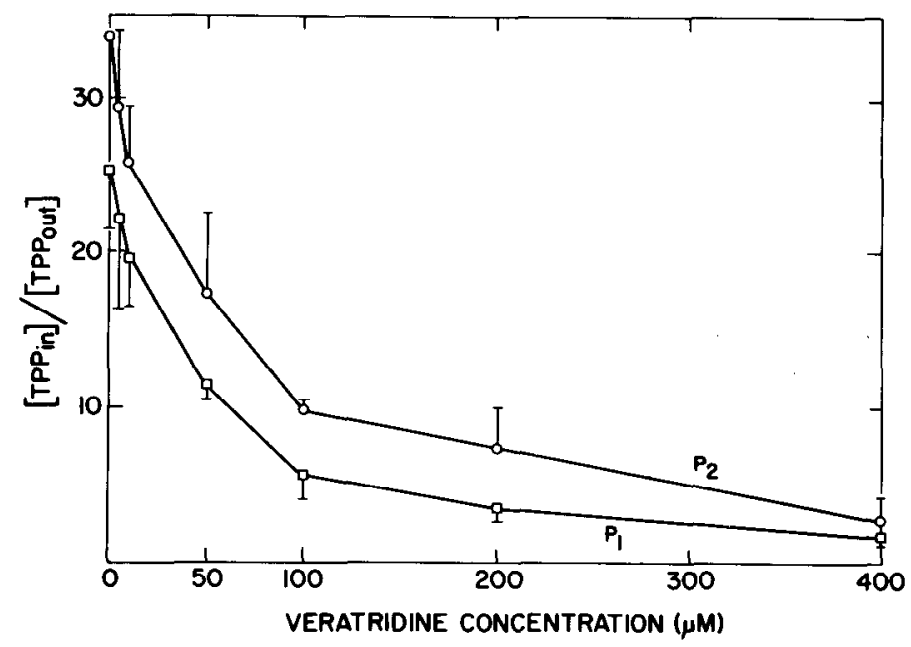

Figure 5. Effect of veratridine on the $\mathrm{TPP}^{+}$concentration gradient. Synaptosomes were incubated for $5 \mathrm{~min}$ in the absence or in the presence of increasing concentrations of veratridine. $\square$, Fraction $P_{1} ; O$, fraction $P_{2}$. The values represent mean $\pm S D$ for three preparations. 


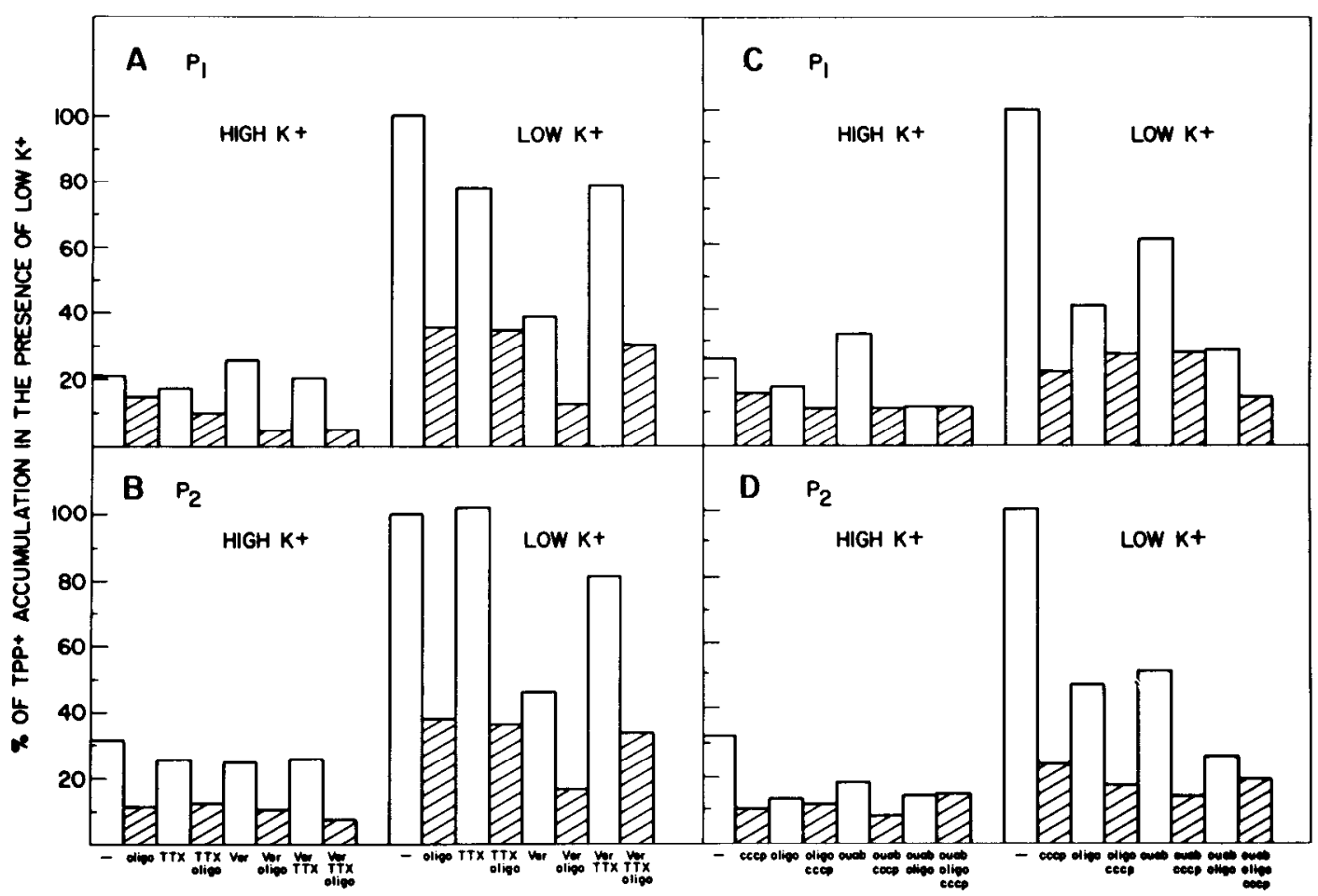

Figure 6. Characterization of $\mathrm{TPP}^{+}$accumulation. Synaptosomes were allowed to equilibrate with buffer, drugs, and air or argon for $5 \mathrm{~min}$ before $\mathrm{TPP}^{+}$addition. $\mathrm{TPP}^{+}$accumulation into fractions $\mathrm{P}_{1}$ or $\mathrm{P}_{2}$ was measured in high $\mathrm{K}^{+}$or low $\mathrm{K}^{+}$medium. Relative accumulation under each condition was calculated using accumulation of $\mathrm{TPP}^{+}$under low $\mathrm{K}^{+}$and air with no drugs as the $100 \%$ value. In panel $A$ (fraction $\mathrm{P}_{1}$ ) and panel $B$ (fraction $\mathrm{P}_{2}$ ), effects of tetrodotoxin $(15 \mu \mathrm{M})$, veratridine $(50 \mu \mathrm{M})$, and oligomycin $(10 \mu \mathrm{g} / \mathrm{ml})$ were compared. Open bars, in air and no oligomycin; hatched bars, under oligomycin/argon. In panel $C$ (fraction $\mathrm{P}_{1}$ ) and panel $D$ (fraction $\mathrm{P}_{2}$ ), effects of oligomycin $(10 \mu \mathrm{g} / \mathrm{ml})$, ouabain $(10 \mathrm{~mm})$, and CCCP $(10 \mu \mathrm{M})$ were compared. Open bars, no CCCP; hatched bars, in the presence of CCCP.

$\mathrm{TPP}^{+}$in the presence of oligomycin/argon as it causes in air (Fig. 6). No effect of veratridine is observed when $\mathrm{Na}^{+}$ is replaced with choline ${ }^{+}$. Tetrodotoxin (TTX) is known to be a specific blocker of action potential sodium channels (Evans, 1972; Narahashi et al., 1964) and, by itself, has no effect on $\mathrm{TPP}^{+}$accumulation in either high or low $\mathrm{K}^{+}$medium. However, TTX inhibits the effects of veratridine that are seen at low $\mathrm{K}^{+}$both in the presence and in the absence of oligomycin/argon (Fig. 6). Thus, TTX has no effect on resting $\Delta \Psi$, but it can prevent the depolarizing effect of veratridine in synaptosomal fractions (Table IV).

Ouabain had no effect on $\mathrm{TPP}^{+}$accumulation at high $\mathrm{K}^{+}$, but it reduced $\mathrm{TPP}^{+}$accumulation in low $\mathrm{K}^{+}$in the presence or in the absence of oligomycin/argon (Figs. 4 and 6), indicating that ouabain reduces only the synaptosomal $\Delta \Psi$ with no direct effect on the mitochondrial $\Delta \Psi$. The effects of ouabain at saturating levels and veratridine at unsaturating levels were additive. The protonophore CCCP, which is expected to collapse the synaptosomal plasma membrane $\Delta \Psi$ and the mitochondrial $\Delta \Psi$, reduced the accumulation of $\mathrm{TPP}^{+}$to very low levels in both high and low $\mathrm{K}^{+}$media. No further reduction of $\mathrm{TPP}^{+}$accumulation could be detected in the presence of CCCP when oligomycin/argon or ouabain were added alone or in combination (Fig. 6). The cause of the residual $\mathrm{TPP}^{+}$accumulation in the presence of CCCP (Table IV) is unknown.
Influence of $T P P^{+}$concentrations on $T P P^{+}$accumulation. Synaptosomal TPP ${ }^{+}$accumulation was observed to behave as an inverse function of external $\mathrm{TPP}^{+}$concentration in the range of 0.5 to $100 \mu \mathrm{M}$ so that increasing external $\mathrm{TPP}^{+}$resulted in reduction of the apparent $\Delta \Psi$ (Fig. 7). A possible explanation for this phenomenon may be derived from the following consideration: if one assumes a plasma membrane potential of $-66 \mathrm{mV}$ (based on our oligomycin/argon results) and a mitochondrial $\Delta \Psi$ of $-120 \mathrm{mV}$ (according to Scott and Nicholls, 1980), then at $5 \mu \mathrm{M}$ external $\mathrm{TPP}^{+}$, the synaptic cytoplasm would contain about $60 \mu \mathrm{M} \mathrm{TPP}^{+}$, while the concentration of TPP $^{\prime}$ in the intrasynaptosomal mitochondria would be about $6 \mathrm{mM}$. Furthermore, as the external TPP ${ }^{+}$ concentration rises, the $\mathrm{TPP}^{+}$concentration in the intrasynaptosomal mitochondria also would be expected to rise and finally attain levels such that $\mathrm{TPP}^{+}$no longer behaves as an inert component in the system. This would lead to collapse of the electrical gradient existing across the mitochondrial membrane.

Thus, as the medium concentrations of $\mathrm{TPP}^{+}$increase, the fraction of intrasynaptosomal $\mathrm{TPP}^{+}$, which is extramitochondrial, increases such that, at external $\mathrm{TPP}^{+}$ concentrations in excess of $50 \mu \mathrm{M}$, virtually all of the $\mathrm{TPP}^{+}$accumulation would be extramitochondrial. To test this hypothesis, the accumulation of $\mathrm{TPP}^{+}$into the synaptosomal fractions was monitored as a function of medium $\mathrm{TPP}^{+}$concentration in the presence and in the 
TABLE IV

Synaptosomal membrane potential changes as a result of drugs

Membrane potentials were calculated from the difference of $\mathrm{TPP}^{+}$uptake in low and high potassium under each drug and are the average from two separate preparations (each in duplicate). Experimental details are described in the legend to Figure 6.

A. Effects of veratridine (Ver) and tetrodotoxin (TTX)

\begin{tabular}{|c|c|c|c|c|c|}
\hline \multirow{2}{*}{$\begin{array}{l}\text { Tissue } \\
\text { Fraction }\end{array}$} & \multirow{2}{*}{$\begin{array}{l}\text { Oligomycin/Argon } \\
(10 \mu \mathrm{g} / \mathrm{ml})\end{array}$} & \multicolumn{4}{|c|}{ Membrane Potential } \\
\hline & & Control & Ver & TTX & Ver and TTX \\
\hline & & & & & \\
\hline \multirow[t]{2}{*}{$P_{1}$} & + & 61.2 & 29.1 & 66.8 & 59.1 \\
\hline & - & 95.9 & 43.2 & 91.5 & 84.3 \\
\hline \multirow[t]{2}{*}{$\mathbf{P}_{2}$} & + & 69.0 & 31.9 & 67.1 & 69.7 \\
\hline & - & 95.5 & 64.1 & 95.7 & 90.3 \\
\hline
\end{tabular}

B. Effects of ouabain (Oua) and carbonyl cyanide $m$-chlorophenyl hydrazone (CCCP)

\begin{tabular}{|c|c|c|c|c|c|}
\hline \multirow{2}{*}{$\begin{array}{l}\text { Tissue } \\
\text { Fraction }\end{array}$} & \multirow{2}{*}{$\begin{array}{l}\text { Oligomycin/Argon } \\
(10 \mu \mathrm{g} / \mathrm{ml})\end{array}$} & \multicolumn{4}{|c|}{ Membrane Potential } \\
\hline & & Control & Oua & $\mathrm{CCCP}$ & $\mathrm{CCCP}$ and Oua \\
\hline & & & & & \\
\hline$P_{1}$ & - & 95.1 & 71.5 & 17.3 & 29.9 \\
\hline \multirow[t]{2}{*}{$\mathrm{P}_{2}$} & + & 76.3 & 56.2 & 36.2 & 31.6 \\
\hline & - & 89.6 & 79.2 & 46.1 & 33.7 \\
\hline
\end{tabular}

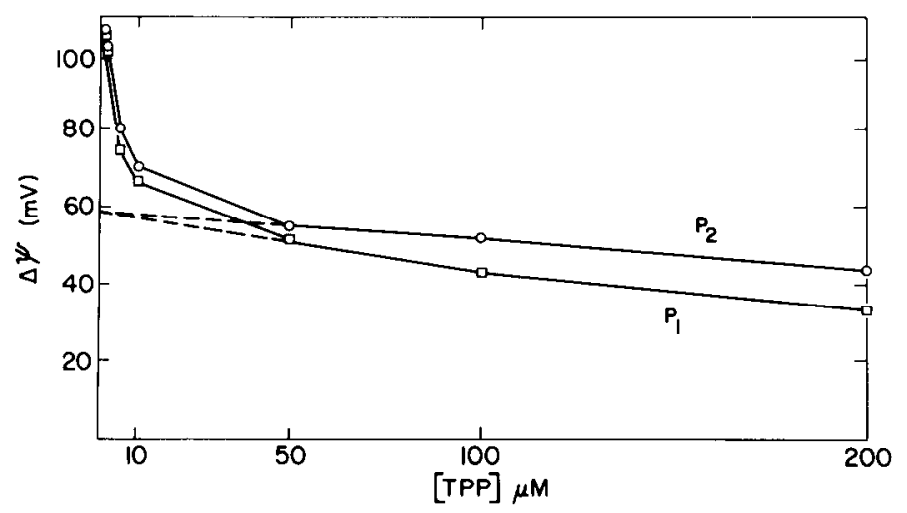

Figure 7. Synaptosomal $\mathrm{TPP}^{+}$accumulation as a function of $\mathrm{TPP}^{+}$concentration. $\mathrm{TPP}^{+}$accumulation proceeded for $5 \mathrm{~min}$ at $37^{\circ} \mathrm{C}$ in the presence of external $\mathrm{TPP}^{+}$concentrations ranging from 0.5 to $200 \mu \mathrm{M} . \Delta \Psi$ was calculated for fraction $P_{1}(\square)$ and fraction $\mathrm{P}_{2}(\mathrm{O})$. The dotted line is the extrapolation of the plateau slope to $0 \mathrm{TPP}^{+}$concentration. Data are the means of three preparations.

absence of oligomycin/argon. However, in the presence of oligomycin/argon, TPP ${ }^{+}$accumulation was independent of the external $\mathrm{TPP}^{+}$concentration (Table V). The mitochondrial $\Delta \Psi$ has been calculated based on $(i)$ the difference in $\mathrm{TPP}^{+}$accumulation in the presence versus the absence of oligomycin/argon (Table V) and (ii) the assumption that the intrasynaptosomal mitochondria represent about $10 \%$ of the total internal volume (according to Scott and Nicholls, 1980). At $1 \mu \mathrm{M} \mathrm{TPP}^{+}$, the observed mitochondrial $\Delta \Psi$ of $-110 \mathrm{mV}$ is in excellent agreement with values reported in the literature (Mitchell and Moyle, 1969). The mitochondrial content of TPP ${ }^{+}$ does not increase proportionally as the external $\mathrm{TPP}^{+}$ concentration rises, indicating that the mitochondrial $\Delta \Psi$ declines progressively with increasing $\mathrm{TPP}^{+}$concentrations (Table V), presumably due to dissipation of the mitochondria $\Delta \Psi$ by the high internal $\mathrm{TPP}^{+}$concentration. ${ }^{5}$

\section{Discussion}

The data in this paper demonstrate that the plasma membrane potential of olfactory bulb synaptosomal preparations can be quantitated from measurements of the steady state accumulation of the lipophilic cation tetraphenylphosphonium. However, due to a significant and variable contribution of mitochondrial $\mathrm{TPP}^{+}$accumulation to total $\mathrm{TPP}^{+}$accumulation in the synaptosomal preparation, an accurate calculation of plasma membrane $\Delta \Psi$ can be performed only under certain conditions. A contribution of the mitochondrial potential to total $\mathrm{TPP}^{+}$accumulation was expected (Mitchell and Moyle, 1969; Nicholls, 1974; Rottenberg, 1979) as mitochondria exhibit a negative internal potential. The mitochondrial contribution can be derived by comparing $\mathrm{TPP}^{+}$accumulation under air versus its accumulation in the presence of oligomycin/argon. If one inserts both the mitochondrial and the plasma membrane potential contribution to $\mathrm{TPP}^{+}$accumulation into the Nernst equation (as was described by Scott and Nicholls, 1979; $s=$ synaptosomal, $e=$ external, $\Delta \Psi_{p}=\Delta \Psi$ of plasma membrane, $\Delta \Psi_{m}=\Delta \Psi$ of mitochondria, $V_{c}=$ cytoplasmic volume, and $V_{m}=$ mitochondrial volume), one obtains:

$$
\frac{\left[\mathrm{TPP}^{+} s\right]}{\left[\mathrm{TPP}^{+} e\right]}=\frac{V_{c} \cdot 10^{\Delta \Psi_{p} / 61.5}+V_{m} \cdot 10^{\left(\Delta \Psi_{m}+\Delta \Psi_{p}\right) / 61.5}}{V_{c}+V_{m}}
$$

Resolving the equation for the measurable parameters of

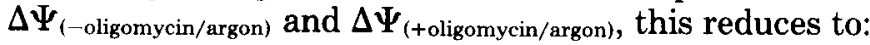

$$
\frac{\left[\mathrm{TPP}^{+} s\right]}{\left[\mathrm{TPP}^{+} e\right]}=\frac{V_{c}+V_{m} \cdot 10^{\Delta \psi_{m} / 61.5}}{V_{c}+V_{m}} \cdot 10^{\Delta \Psi_{p} / 61.5}
$$

\footnotetext{
${ }^{5}$ It is worth noting in passing that administration of $\mathrm{TPP}^{+}$to mice at whole body doses equivalent to $50 \mu \mathrm{M}$ resulted in the death of six out of seven animals within 4 days.
} 
TABLE V

$T P P^{+}$toxicity to mitochondria ( $P_{2}$ fraction $)$

\begin{tabular}{|c|c|c|c|c|c|c|}
\hline \multirow{2}{*}{$\begin{array}{c}\text { Time after Addition of } \\
\text { TPP }^{+}\end{array}$} & \multirow{2}{*}{$\mathrm{TPP}^{+}$} & \multicolumn{2}{|c|}{$\Delta \Psi$ Total } & \multirow{2}{*}{$\begin{array}{c}\Delta \Psi \\
\text { Mitochondria }^{a}\end{array}$} & \multicolumn{2}{|c|}{$\begin{array}{c}{\left[\mathrm{TPP}^{+}\right]_{\text {in }}} \\
\text { Mitochondria }\end{array}$} \\
\hline & & + Oligo/Ar & -Oligo/Ar & & Calculated & Expected $^{h}$ \\
\hline $\min$ & $\mu_{M}$ & & & & & \\
\hline \multirow[t]{3}{*}{5} & 1 & 60.3 & 110.0 & 106.7 & 0.52 & 1.2 \\
\hline & 5 & 60.2 & 92.6 & 84.4 & 1.13 & 6.0 \\
\hline & 50 & 46.9 & 63.4 & 57.2 & 2.46 & 60.0 \\
\hline \multirow[t]{3}{*}{10} & 1 & 56.6 & 114.3 & 108.5 & 0.66 & 1.2 \\
\hline & 5 & 54.9 & 96.1 & 96.3 & 1.44 & 6.0 \\
\hline & 50 & 54.5 & 57.7 & 6.4 & 0.49 & 60.0 \\
\hline
\end{tabular}

" $\Delta \Psi$ mitochondria was calculated from the difference between $\mathrm{TPP}^{+}$accumulation in the absence and in the presence of oligomycin/argon

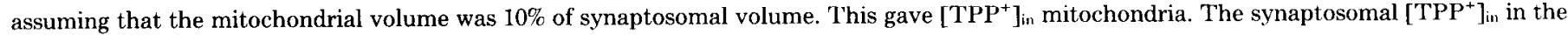
presence of oligomycin was taken as the mitochondrial $\left[\mathrm{TPP}^{+}\right]_{\text {out }} \Delta \Psi$ was calculated as:

$$
61.5 \log \frac{\left[\mathrm{TPP}^{+}\right]_{\text {in }} \text { mitochondria }}{\left[\mathrm{TPP}^{+}\right]_{\text {out }} \text { mitochondria }}
$$

\footnotetext{
${ }^{b}$ The expected concentration of $\mathrm{TPP}^{+}$inside of the mitochondria was calculated from the $\mathrm{TPP}^{+}$concentration inside of the synaptosomes, assuming a mitochondrial potential of $120 \mathrm{mV}$ or a $\mathrm{TPP}^{+}$gradient of 100 .
}

or:

$$
61.5 \log \frac{\left[\mathrm{TPP}^{+} s\right]}{\left[\mathrm{TPP}^{+} e\right]}=61.5 \log \frac{V_{c}+V_{m} \cdot 10^{\Delta \Psi_{m} / 61.5}}{V_{c}+V_{m}}+\Delta \Psi_{p}
$$

which simplified to:

$$
\Delta \Psi_{(- \text {oligomycin/argon })}=a+\Delta \Psi_{i+\text { oligormycin/argon })}
$$

where parameter $a$ replaces the mitochondrial contribution factor. Parameter $a$ is constant when the mitochondrial potential and the volume are constant. Under this condition, this equation predicts a linear relationship between $\Delta \Psi_{(- \text {oligomycin/argon) }}$ and $\Delta \Psi_{(+ \text {oligomycin/argon). }}$ This relationship was actually obtained with a slope of 1 as predicted by the equation and gave values of $-25 \mathrm{mV}$ for $\mathrm{P}_{1}$ and $-22 \mathrm{mV}$ for $\mathrm{P}_{2}$ (Fig. 3). The mitochondrial accumulation of $\mathrm{TPP}^{+}$decreased as a function of increasing concentration of $\mathrm{TPP}^{+}$in the range from 0.1 to $200 \mu \mathrm{M}$ $\mathrm{TPP}^{+}$, while no such change was observed in the plasma membrane $\Delta \Psi$-dependent accumulation of ' $\mathrm{THP}^{+}$. This demonstrates that $\mathrm{TPP}^{+}$itself interferes with the mitochondrial membrane potential under aerobic conditions.

Therefore, changes in the plasma membrane potential of olfactory bulb synaptosomes can be evaluated by $\mathrm{TPP}^{+}$accumulation quantitatively in the presence of oligomycin/argon, where the mitochondrial contribution is eliminated, or qualitatively in the absence of oligomycin/argon, if the drug in question does not affect the mitochondrial potential. Our data suggest that a second approach to overcome the mitochondrial contribution to $\mathrm{TPP}^{+}$accumulation is to use high enough $\mathrm{TPP}^{+}$concentrations to block mitochondrial function and subsequent back extrapolation to estimate plasma membrane $\Delta \Psi$ (Fig. 6). This is technically much simpler than the oligomycin/argon approach and, in some situations, may be equivalent.

Utilizing this approach, our results for rat olfactory bulb synaptosomes agree with the qualitative evaluation of the lipophilic cation gradients in guinea pig synaptosomes presented by Ramos et al. (1979) for $\mathrm{TPP}^{+}$and by Creveling et al. (1980) for $\mathrm{TPMP}^{+}$. In addition, by characterizing and eliminating the mitochondrial contribu- tion, we have achieved an accurate quantitative biochemical measurement of synaptosomal membrane $\Delta \Psi$ which previously could be estimated only qualitatively with other biochemical techniques.

The properties of the olfactory bulb synaptosomal plasma membrane potential were found to be similar to those of nerve cells according to the following criteria: (a) there is a negative electrical potential $(\Delta \Psi)$ of -64 $\mathrm{mV}$ in $\mathrm{P}_{1}$ and $-77 \mathrm{mV}$ in $\mathrm{P}_{2}$ synaptosomes. (b) These $\Delta \Psi$ values are due primarily to a $\mathrm{K}^{+}$diffusion gradient across the synaptosomal membrane, as indicated by increased depolarization as a result of increasing external concentrations of $\mathrm{K}^{+}$, and no large change when $\mathrm{Na}^{+}$is replaced by cholinc ${ }^{+}$. A corrclation of $\Delta \Psi$ with the logarithm of external $\mathrm{K}^{+}$concentration resulted in a limiting slope of 50 instead of 61.5 as predicted by the Nernst equation. This difference is similar to that noted previously by Hodgkin and Keynes (1955) for the squid giant axon. 'The deviation from the linear relationship that was observed for this synaptosomal preparation at external concentrations of $\mathrm{K}^{+}$below $10 \mathrm{~mm}$ was similar to that observed by electrophysiological measurements in other neural cells (Hodgkin and Keynes, 1955; Gorman and Marmor, 1970; Eyzaguirre and Fidone, 1975) and has been attributed to a small sodium permeability. (c) A minor role for the contribution of active sodium transport to $\Delta \Psi$ was expressed in our studies by the depolarization which occurred in the presence of ouabain as well as by the slight hyperpolarization observed when choline replaced $\mathrm{Na}^{+}$in the incubation medium. (d) A role for $\left(\mathrm{Na}^{+}, \mathrm{K}^{+}\right)$-ATPase in maintaining the synaptic plasma membrane potential is based on the inhibition of the $\left(\mathrm{Na}^{+}, \mathrm{K}^{+}\right)$-ATPase by ouabain. Ouabain causes a rapid depolarization with a $t_{1 / 2}$ of $30 \mathrm{sec}$ without any detectable loss of internal $\mathrm{K}^{+}$, indicating an electrogenic role for the $\left(\mathrm{Na}^{+}, \mathrm{K}^{+}\right)$-ATPase in synaptosomes which contributes about -10 to $-20 \mathrm{mV}$ to the membrane potential. This finding agrees with Gorman and Marmor (1970) and Thomas (1972), whose studies also suggested an electrogenic role for the $\left(\mathrm{Na}^{+}, \mathrm{K}^{+}\right)$-ATPase. The slow depolarizing effect of ouabain is most likely due to the inability 
of ouabain-inhibited synaptosomes to re-accumulate $\mathrm{K}^{+}$ that has leaked out with the resultant lower $\left[\mathrm{K}^{+}\right]_{\text {in }} /$ $\left[\mathrm{K}^{+}\right]_{\text {out }}$ ratio. The $80 \%$ loss of internal $\mathrm{K}^{+}$as observed by atomic absorption spectrometry $1 \mathrm{hr}$ after ouabain addition to synaptosomes (S. Rochel, D. Lichtstein, A. J. Blume, and F. L. Margolis, unpublished observations) supports this hypothesis. (e) The existence of a veratridine-sensitive sodium channel through which veratridine caused a decrease in $\mathrm{TPP}^{+}$accumulation into synaptosomes was found. This effect of veratridine was blocked by tetrodotoxin and was not observed when sodium was replaced by choline in the extrasynaptosomal medium. These observations are consistent with the existence of an action potential sodium channel of the type known in whole nerve cells (Narahashi et al., 1964; Ulbricht, 1969; Evans, 1972; Catterall and Nirenberg, 1973).

In summary, measurements of the distribution of the lipophilic cation tetraphenylphosphonium have been used to characterize the plasma membrane potential of synaptosomal fractions from rat olfactory bulbs. When the mitochondrial contribution to $\mathrm{TPP}^{+}$accumulation was eliminated, synaptosomal plasma membrane $\Delta \Psi$ properties were found to be similar to neuronal $\Delta \Psi$ obtained by electrophysiological measurements. As the $\mathrm{TPP}^{+}$measurements must be carried out at steady state in order to be used to quantitate $\Delta \Psi$, this probe is not suitable for the study of the effects of neurotransmitters which result in rapid (millisecond) and reversible changes in the membrane potential. The influence of various drugs with long term effects on the plasma membrane potential and the role of certain ions in maintaining the plasma membrane potential can be studied conveniently with this lipophilic cation as exemplified by our studies. Thus, $\mathrm{TPP}^{+}$accumulation into synaptosomes can be used to monitor long term changes in neuronal membrane $\Delta \Psi$ generated by slowly acting hormones or neuromodulators with time courses of seconds to hours. It would be of interest to evaluate the use of $\mathrm{TPP}^{+}$in the millisecond range (using a stop flow system under nonsteady state conditions) as a $\Delta \Psi$ probe for the detection of short term events. Lastly, as the olfactory bulb was found to contain several types of peptide neurotransmitters and hormones, the application of $\mathrm{TPP}^{+}$as a $\Delta \Psi$ probe should be very useful in studying the role of these peptides in the olfactory pathway.

\section{References}

Arieff, A., A. Kerian, S. G. Massry, and J. DeLima (1976) Intracellular $\mathrm{pH}$ of brain: Alterations in acute respiratory acidosis and alkalosis. Am. J. Physiol. 230: 804-812.

Baker, P. F. (1965) Phosphorus metabolism of intact crab nerve and its relation to the active transport of ions. J. Physiol. (Lond.) 180: 383-423.

Baldessarini, R. J., and M. Karobath (1973) Biochemical physiology of central synapses. Annu. Rev. Physiol. 35: 273-304.

Baxter, C. (1972) Assay of $\gamma$-aminobutyric acid and enzymes involved in its metabolism. In Methods of Neurochemistry, R. Fried, ed., Vol. 3, pp. 1-73, Marcel Dekker, Inc., New York.

Blaustein, M. P., and J. M. Goldring (1975) Membrane potentials in pinched-off presynaptic nerve terminals, monitored with a fluorescent probe: Evidence that synaptosomes have potassium diffusion potentials. J. Physiol. (Lond.) 247: 589_ 615

Bradford, H. F. (1969) Respiration in vitro of synaptosomes from the mammalian cerebral cortex. J. Neurochem. 16: 675684.

Bradford, H. F. (1975) Isolated nerve terminals as an in vitro preparation for the study of dynamic aspects of transmitter metabolism and release. In Handbook of Psychopharmacology, L. L. Iversen, S. D. Iversen, and S. H. Snyder, eds., Vol. 1, pp. 191-252, Plenum Press, New York.

Burton, K. (1956) A study of the conditions and mechanisms of diphenylamine reaction for the colorimetric estimation of deoxyribonucleic acid. Biochem. J. 62: 315-323.

Campbell, C. W. B. (1976) The $\mathrm{Na}^{+}, \mathrm{K}^{+}, \mathrm{Cl}^{-}$contents and derived membrane potentials of presynaptic nerve endings in vitro. Brain Res. 101: 594-599.

Catterall, W. A., and M. Nirenberg (1973) Sodium uptake associated with activation of action potential ionophores of cultured neuroblastoma and muscle cells. Proc. Natl. Acad. Sci. U. S. A. 70: 3759-3763.

Cotman, C. W., and D. A. Flansburg (1970) An analytical micro method for electron microscopic study of the composition and sedimentation properties of subcellular fractions. Brain Res. 22: 152-156.

Cotman, C. W., L. W. Haycock, and W. F. White (1976) Stimulus-secretion coupling processes in brain: Analysis of noradrenaline and gamma-aminobutyric acid release. J. Physiol. (Lond.) 254: 475-505.

Creveling, C. R., E. T. McNael, D. H. McCulloh, and W. H Daly (1980) Membrane potentials in cell free preparation from guinea pig cerebral cortex: Effect of depolarizing agents and cyclic nucleotides. J. Neurochem. 35: 922-932.

Dahl, J. L., and L. E. Hokin (1974) The sodium-potassium adenosine triphosphatase. Annu. Rev. Biochem. 43: 327-356.

Evans, M. H. (1972) Tetrodotoxin, saxitoxin and related substances: Their applications in neurobiology. Int. Rev. Neurobiol. 15: 83-166.

Eyzaguirre, C., and S. J. Fidone, eds. (1975) Physiology of the Nervous System, Year Book Medical Publishers, Inc., Chicago.

Ferriero, D., and F. L. Margolis (1975) Denervation in the primary olfactory pathway of micc. II. Effects on carnosine and other amine compounds. Brain Res. 94: 75-86.

Glynn, I. M., and S. J. D. Karlish (1975) The sodium pump. Annu. Rev. Physiol. 37: 13-55.

Gorman, A. F. L., and M. F. Marmor (1970) Contributions of the sodium pump and ionic gradients to the membrane potential of molluscan neurons. J. Physiol. (Lond.) 210: 897917.

Grinius, L. L., A. A. Jasaitis, Y. P. Kadziauskas, E. A. Liberman, V. P. Skulachev, V. P. Topali, L. M. Tsofina, and M. A. Vladimirova (1970) Conversion of biomembrane-produced energy into electric form. Biochim. Biophys. Acta 216: 1-12.

Hajos, F., R. Tapia, G. Wilkin, A. L. Johnson, and R. Balázs (1974) Subcellular fractionation of rat cerebellum: An electron microscopic and biochemical investigation. I. Preservation of large fragments of the cerebellar glomeruli. Brain Res. 70: 261-279.

Hansson, E., I. Jacobson, R. Venema, and A. Sellström (1980) Measurement of the membrane potential of isolated nerve terminals by the lipophilic cation $\left[{ }^{3} \mathrm{H}\right]$ triphenylmethylphosphonium bromide. J. Neurochem. 34: 569-573.

Hirsch, J. D., and F. L. Margolis (1979) L- $\left[{ }^{3} \mathrm{H}\right]$ Carnosine binding in the olfactory bulb. II. Biochemical and biological studies. Brain Res. 171: 81-94.

Hirsch, J. D., M. Grillo, and F. L. Margolis (1978) Ligand binding studies in the mouse olfactory bulb: Identification and characterization of a $\left[{ }^{3} \mathrm{H}\right]$ carnosine binding site. Brain Res. 158: 407-422.

Hodgkin, A. L., and R. D. Keynes (1955) The potassium permeability of giant nerve fibre. J. Physiol. (Lond.) 128: 61-88.

Keen, P., and T. D. White (1971) The permeability of pinched- 
off nerve endings to sodium, potassium and chloride and the effects of gramicidin. J. Neurochem. 18: 1097-1103.

Keller, A. (1975) Studies with a protein purified from rat olfactory bulbs, which is specific to the olfactory chemoreceptor neuron. Doctoral dissertation, City University of New York.

Kinnally, K. W., and H. Tedeschi (1977) Electrofluorometric estimates of membrane potential in metabolizing mitochondria. Biophys. J. 17: 33a.

Kornguth, S. E., G. Scott, and R. Jaramillo (1979) Ultrastructural and biochemical comparisons of dendrodendritic synaptosomes from bovine superior colliculi and olfactory bulbs with axodendritic and axosomatic synaptosomes. J. Neurochem. 33: 875-882.

Krasne, S. (1977) Cyanine dye-induced electrical and fluorescence effects in neutral and negative bilayer membranes. Biophys. J. 17: 214a.

Levi, G., and M. Raiteri (1976) Synaptosomal transport processes. Int. Rev. Neurobiol. 19: 51-74.

Li, P. P., and T. D. White (1977) Rapid effects of veratridine, tetrodotoxin, Gramicidin $\mathrm{O}$, valinomycin and $\mathrm{NaCN}$ on the $\mathrm{Na}^{+}, \mathrm{K}^{+}$and ATP contents of synaptosomes. J. Neurochem. 28: 967-975.

Lichtstein, D., H. R. Kaback, and A. J. Blume (1979) Use of lipophilic cation for determination of membrane potential in neuroblastoma-glioma hybrid cell suspensions. Proc. Natl. Acad. Sci. U. S. A. 76: 650-654.

Margolis, F. L. (1974) Carnosine in the primary olfactory pathway. Science 184: 909-911.

Margolis, F. L. (1981) Neurotransmitter biochemistry of the mammalian olfactory bulb. In Biochemistry of Taste and Olfaction, R. H. Cagan and M. R. Kare, eds., pp. 369-394, Academic Press, New York.

Margolis, F. L., and M. Grillo (1977) Axoplasmic transport of carnosine ( $\beta$-alanyl-alanyl-L-histidine) in the mouse olfactory pathway. Neurochem. Res. 2: 507-519.

Margolis, F. L., N. Roberts, D. Ferriero, and J. Feldman (1974) Denervation in the primary olfactory pathway of mice: Biochemical morphological effects. Brain Res. 81: 469-483.

Mitchell, P., and J. Moyle (1969) Estimation of membrane potential and $\mathrm{pH}$ difference across the cristae membrane of rat liver mitochondria. Eur. J. Biochem. 7: 471-484.

Montecucco, C., T. Pozzan, and T. Rink (1979) Dicarbocyanine fluorescent probes of membrane potential block lymphocyte capping, deplete cellular ATP and inhibit respiration of isolated mitochondria. Biochim. Biophys. Acta 552: 552-557.

Nadi, N. S., J. D. Hirsch, and F. Margolis (1980a) Laminar distribution of putative neurotransmitter amino acids and ligand binding sites in the dog olfactory bulb. J. Neurochem. 34: 138-146.

Nadi, N. S., R. Head, M. Grillo, J. Hempstead, N. GrannotReisfeld, and F. L. Margolis (1980b) Chemical deafferentation of the olfactory bulb: Plasticity of the levels of tyrosine hydroxylase, dopamine and norepinephrine. Brain Res. 213: 365-377.

Narahashi, T., J. W. Moore, and W. R. Scott (1964) Tetrodotoxin blockage of sodium conductance increase in lobster giant axons. J. Gen. Physiol. 47: 965-974.

$\mathrm{Ng}, \mathrm{R}$. H., and B. D. Howard (1978) Deenergization of nerve terminals by $\beta$-bungarotoxin. Biochemistry 17: 4978-4986.

Nicholls, D. G. (1974) The influence of respiration and ATP hydrolysis on the proton-electrochemical gradient across the inner membrane of rat liver mitochondria as determined by ion distribution. Eur. J. Biochem. 50: 305-315.

Quinn, M. R., and R. H. Cagan (1980) Subcellular distribution of glutamate decarboxylase rat olfactory bulb: High content in dendrodendritic synaptosomes. J. Neurochem. 35: 583590.

Ramos, S., E. F. Grollman, P. S. Lazo, S. A. Dyer, W. H. Habig, M. C. Hardegree, H. R. Kaback, and L. D. Kohn (1979) Effect of tetanus toxin on the accumulation of the permeant lipophilic cation tetraphenylphosphonium by guinea pig brain synaptosomes. Proc. Natl. Acad. Sci. U. S. A. 76: 4783-4787.

Rottenherg, H. (1979) The measurement of membrane potential and $\Delta \mathrm{pH}$ in cells, organelles and vesicles. Methods Enzymol. 55: $547-569$.

Schatzmann, H. J. (1965) The role of $\mathrm{Na}^{+}$and $\mathrm{K}^{+}$in the ouabain inhibition of the $\mathrm{Na}^{+}+\mathrm{K}^{+}$activated membrane adenosine triphosphatase. Biochim. Biophys. Acta 94: 89-96.

Schuldiner, S., and H. R. Kaback (1975) Membrane potential and active transport in membrane vesicles from Escherichia coli. Biochemistry 14: 5451-5461.

Scott, I. D., and D. G. Nicholls (1979) The estimation of the electrical potential across the inner membrane of mitochondria with intact synaptosomes. Biochem. Soc. Trans. 7: 969970.

Scott, I. D., and D. G. Nicholls (1980) Energy transduction in intact synaptosomes. Influence of plasma-membrane depolarization on the respiration and membrane potential of internal mitochondria determined in situ. Biochem. J. 186: 2133.

Sedmak, J. J., and S. E. Grossberg (1977) A rapid, sensitive and versatile assay for protein using Coomassie Brilliant Blue G250. Anal. Biochem. 79: 544-552.

Sen, I., and J. R. Cooper (1978) Similarity of $\beta$-bungarotoxin and phospholipase $A_{2}$ and their mechanism of action. $J$. Neurochem. 30: 1369-1375.

Shepherd, G. M. (1977) The olfactory bulb: A simple system in the mammalian brain. In Handbook of Physiology. Vol. 1: Cellular Biology of Neurons, Part 2. Sect. 1: The Nervous System, J. M. Brookhart, V. B. Mountcastle, E. R. Kandel, and S. R. Geiger, eds., pp. 945-968, The American Physiological Society, Bethesda, MD.

Simons, T. J. B. (1976) Carbocyanine dyes inhibit Ca-dependent $\mathrm{K}^{+}$efflux from human red cell ghosts. Nature 264: 467-469.

Sims, P. J., A. S. Waggoner, C. -H. Wang, and J. F. Hoffman (1974) Studies on the mechanism by which cyanine dyes measure membrane potential in red blood cells and phosphatidylcholine vesicles. Biochemistry 13: 3315-3330.

Smith, T. W., and E. Haber (1973) Digitalis (first of four parts). N. Engl. J. Med. 289: 945-952.

Sundt, R. M., and R. E. Anderson (1980) Intracellular brain $\mathbf{p H}$ and the pathway of a fat soluble $\mathrm{pH}$ indicator across the blood-brain barrier. Brain Res. 186: 355-364.

Thomas, R. C. (1972) Electrogenic sodium pump in nerve and muscle cells. Physiol. Rev. 52: 563-594.

Ulbricht, W. (1969) The effect of veratridine on excitable membranes of nerve and muscle. Ergeb. Physiol. Biol. Chem. Exp. Pharmakol. 61: 18-71.

Wallick, E. T., L. K. Lane, and A. Schwartz (1979) Biochemical mechanism of the sodium pump. Annu. Rev. Physiol. 41: 397-411.

White, 'T. U., and P. Keen (1979) 'l'he role of internal and external $\mathrm{Na}^{+}$and $\mathrm{K}^{+}$on the uptake of $\left[{ }^{3} \mathrm{H}\right]$-noradrenaline by synaptosomes prepared from rat brain. Biochim. Biophys. Acta 196: 285-295.

Whittaker, V. P. (1969) The synaptosomes. In Handbook of Neurochemistry, A. Lajtha, ed., Vol. 2, pp. 327-364, Plenum Press, New York.

Wideman, J., L. Brink, and S. Stein (1978) New automated fluorometric peptide microassay for carnosine in mouse olfactory bulb. Anal. Biochem. 86: 670-678. 